\title{
A Brief Description on Impersonal Constructions in Uyghur
}

\author{
Muzappar Abdurusul \\ Institute of Ethnology and Anthropology, Chinese Academy of Social Sciences, Beijing, China
}

Email address:

muzappar@cass.org.cn, muzappar@gmail.com

\section{To cite this article:}

Muzappar Abdurusul. A Brief Description on Impersonal Constructions in Uyghur. International Journal of Language and Linguistics. Vol. 7, No. 4, 2019, pp. 158-165. doi: 10.11648/j.ijl1.20190704.13

Received: June 13, 2019; Accepted: July 8, 2019; Published: July 17, 2019

\begin{abstract}
Impersonal constructions have been a regular topic of investigation in various languages which belong to different language families across the world. Discussions over Impersonal constructions would constitute main contribution to the theoretical study. Although impersonal constructions are the main characteristics of Uyghur, but it's been hardly noticed by theoretical linguists. With this research, I would like to put forward the idea that Uyghur also have a wide variety of impersonal constructions, the analysis of which would bring an interesting contribution to the typology of impersonality. Scholars conceive impersonal constructions in different terms, some apply morphological methods, and others adopt syntactic approaches. Whichever methodology they apply, it is unarguable that impersonal constructions are agentless by nature, in which the sentences may not have an overt subject. They are many varieties of types, such as agentless gerunds, agentless passives, existential sentences etc. Since Uyghur is a pro-drop language, omitting the pronominal subject also helps to form impersonal constructions. This paper provides a brief description on the types of impersonal constructions, explicates several ways of forming agentless sentences, and introduces main types of impersonal sentences in Uyghur.
\end{abstract}

Keywords: Impersonal Constructions, Uyghur, Typology and Formation

\section{Introduction}

Impersonal constructions have been a regular topic of investigation in Indo-European studies, and similar constructions have been described in languages spoken in various areas of the world and belonging to different language families. It had been widely discussed in Anna Siewierska [1, 2], Andrej Malchukov and Anna Siewierska [3], Andrej Malchukov and Akio Ogawa [4] etc.

Modern Uyghur is a direct descendant of old Uighur, which is spoken in western China. Even though Impersonal constructions are one of the major sentence types, we can rarely see exclusive description on them in Uyghur grammars. Some important works such as Hazirqi Zaman Uyghur Tili 'Modern Uyghur Grammar' [5, 6] didn't even mention it. Since most Uyghur Grammarians mainly focused on morphology, detailed information on sentence structures are scarce. In spite of that, there are two well-discussed papers on this topic in Uyghur with Chinese translations. They explained the impersonal constructions from different perspectives. General description on impersonal constructions was published by several linguists. See Xaliq NIYAZ [7], Zäynäp NIYAZ [8],
Niyaz TURDI [9], Cheng at al. [10], Hämit TÖMÜR [11] and Litip TOHTI [12]. Xaliq NIYAZ [7] mainly discussed sentence types in modern Uyghur and classified them according to their properties. He called one of these sentence types as Igisiz Jümlä 'subjectless sentence'. Here, he mainly implied the grammatical subject. Hämit TÖMÜR [11] and Cheng et al. [10] provide general information on Uyghur grammar, only scattered discussions on impersonal constructions can be found in these works. Litip TOHTI [12] thoroughly discussed the syntactic structure of Altaic languages in the frame of Generative Syntax. Page 139-140 includes some discussions on impersonal constructions, where he called them 'agentless sentence. Most of these works cover general discussion without details.

\section{General Description}

Impersonal construction mainly points to agentless construction in Uyghur grammar. The notion 'impersonal' in Uyghur grammar books is disparate because some scholars conceive it in morphological terms, while others adopt syntactic approaches. Most Uyghur grammarians adopt syntactic approach. Nevertheless, they have slightly different 
understandings on the nature of impersonal constructions.

The syntactic characterization of impersonality involves subjecthood. Impersonal constructions are seen to either lack a grammatical subject altogether or alternatively feature only a pleonastic (semantically empty) subject, be it overt one or

$\begin{array}{lll}\text { Üč } & \text { oquyuči } & \text { därs-kä } \\ \text { three } & \text { student } & \text { class-DAT }\end{array}$

'It seems that three students are late to the class.'

Impersonal constructions are identified as having a main verb, normally differentiated for person, which either lacks any person specification altogether or invariably is third person [1]. E.g.:

$\begin{array}{lll}\text { U-nin- } r a & \text { gäp } & \text { öt-mä-ydu. } \\ \text { He-GEN-DAT } & \text { word } & \text { pass-NEG- NPAST }\end{array}$

'He is not persuasive.'

Impersonal passives, in turn, may not lack a thematic

$\begin{array}{lll}\mathrm{Bu} & \text { yär-dä } & \text { jiq } \\ \text { this } & \text { place-LOC } & \text { many }\end{array}$

this place-LOC many

'It is said that one can earn a lot of money here.' covert on [1]. E.g.:

$\begin{array}{lll}\begin{array}{l}\text { Zal-da } \\ \text { hall-LOC }\end{array} & \text { konsert } & \text { bol-iwat-idu. } \\ \text { concert } & \text { be-CONT-NPAST }\end{array}$

'A concert is being held in the hall.'

$\begin{array}{ll}\text { kečik-kän-däk } & \text { tur-idu. } \\ \text { be late- PARTCPL-EQU } & \text { stand-NPAST }\end{array}$

subject but also involve a non-specified human agent, as may also infinitivals and constructions with an invariant $3 \mathrm{Sg}$ form of the verb [1]. E.g.:
Xät
letter
yez-il-di.
write-PASS-PAST

'The letter is written.'

The impersonal use of the 3PL seems to occur only with speech act verbs, particularly in reporting rumors:

$\begin{array}{lll}\text { pul } & \text { tap-qili } & \text { bol-ar-miš. } \\ \text { money } & \text { earn- CONV } & \text { be-AOR-EVID }\end{array}$

\section{The Ways of Forming Agentless Constructions}

Xaliq NIYAZ [7] suggested several fundamental ways of forming agentless constructions. It can be generalized as below:

1) Verbal noun (dative) + bol-. E.g:

\begin{tabular}{|c|c|c|c|}
\hline $\begin{array}{l}\text { Bundaq } \\
\text { such }\end{array}$ & $\begin{array}{l}\text { ähwal-lar-ni } \\
\text { situation-PL-ACC }\end{array}$ & $\begin{array}{l}\text { yänä } \\
\text { again }\end{array}$ & $\begin{array}{l}\text { učrit-iš-qa } \\
\text { encounter-VN-DAT }\end{array}$ \\
\hline
\end{tabular}

'This kind of situation can be seen again.'

\begin{tabular}{|c|c|c|c|c|}
\hline $\begin{array}{l}\mathrm{Bu} \\
\text { this }\end{array}$ & $\begin{array}{l}\text { yär-dä } \\
\text { place-LOC }\end{array}$ & $\begin{array}{l}\text { tamaka } \\
\text { cigarette }\end{array}$ & $\begin{array}{l}\text { ček-iš-kä } \\
\text { smoke-VN-DAT }\end{array}$ & $\begin{array}{l}\text { bol-ma-ydu } \\
\text { be-NEG-NPAST }\end{array}$ \\
\hline
\end{tabular}

'It is forbidden to smoke cigarette here.'

2) Verbal noun (dative) + to rra käl-. E.g:

\begin{tabular}{|c|c|c|c|c|}
\hline $\begin{array}{l}\mathrm{Bu} \\
\text { this }\end{array}$ & $\begin{array}{l}\text { mäsili-ni } \\
\text { problem-ACC }\end{array}$ & $\begin{array}{l}\text { tez } \\
\text { quick }\end{array}$ & $\begin{array}{l}\text { häl } \\
\text { deal with }\end{array}$ & $\begin{array}{l}\text { qil-iš-qa } \\
\text { AUX-VN-DAT }\end{array}$ \\
\hline
\end{tabular}

'This problem should be dealt with quickly.'

3) Intentive adverbials+bol-. E.g:

$\begin{array}{llllll}\text { Bundaq } & \text { yeniliq-lar-ni } & \text { hämmä } & \text { yär-dä } & \text { kör-gili } & \text { bol-idu } \\ \text { such } & \text { new phenomenon-PL-ACC } & \text { all } & \text { place-LOC } & \text { see-CONV } & \text { be-NPAST }\end{array}$

'These new phenomenon can be seen everywhere.'

1) intentive adverbials+time adverbs+bol-. e.g:

$\begin{array}{lllll}\text { Biz } & \text { käl-gili } & \text { ikki } & \text { yil } & \text { bol-di. } \\ \text { we } & \text { come-CONV } & \text { two } & \text { year } & \text { be-PAST }\end{array}$

'It has been two years since we have come.'

Hämit TÖMÜR [11] discussed several types of gerundive impersonals, whose predicates are expressed by the modal adjectives šärt 'necessary', lazim 'should', keräk 'must' or mümkin 'possible, maybe'. E.g:
Waqit-qa
ri'ayä
qil-iš
keräk.
time-DAT
obey
AUX-VN
must

'One must obey the time (one must be punctual).'
Ular-nin
kel-iš-ï
they-GEN
come-VN-POSS.3sg
zörür.
essential 
'It is essential for them to come.'

$\begin{array}{lllll}\text { Biz } & \mathrm{u} & \text { yär-gä } & \text { bar-mas-liq-imiz } & \text { mümkin. } \\ \text { we } & \text { that } & \text { place-DAT } & \text { go-NEG-NOML-POSS.1pl } & \text { may }\end{array}$

'We may not go there.'

When the gerund is in the dative case and combined with the construction toyra käl- 'have to', it produces subjectless sentence which indicate the need for the action to be carried out.

\begin{tabular}{|c|c|c|c|}
\hline $\begin{array}{l}\mathrm{Bu} \\
\text { this }\end{array}$ & $\begin{array}{l}\text { iš-ni } \\
\text { work-ACC }\end{array}$ & $\begin{array}{l}\text { bügün } \\
\text { today }\end{array}$ & $\begin{array}{l}\text { tügit-iš-kä } \\
\text { finish-VN-DAT }\end{array}$ \\
\hline
\end{tabular}

'This work must be completed today.'

When linked with the verb bol- 'to be', it indicates the possibility that the action expressed by the adverbial will be carried out. Such sentences are without subject.

\begin{tabular}{|c|c|c|c|c|}
\hline $\begin{array}{l}\mathrm{Bu} \\
\text { this }\end{array}$ & $\begin{array}{l}\text { iš-ni } \\
\text { work-ACC }\end{array}$ & $\begin{array}{l}\text { ikki } \\
\text { two }\end{array}$ & $\begin{array}{l}\text { kün-dä } \\
\text { day-LOC }\end{array}$ & $\begin{array}{l}\text { tügät-kili } \\
\text { finish-CONV }\end{array}$ \\
\hline
\end{tabular}

'It is possible to finish this job within two days.'

\section{Main Types of Impersonal Sentences}

There are several types of impersonal sentences: agentless sentences, incomplete sentences, existential/ dependent construction, modal sentences etc.

1) agentless sentences

The agent of these sentences are hardly identifiable, it only includes a core sentence which equals to predicate. e.g:

$\begin{array}{lllll}\text { Qiyinčiliq } & \text { ald-i-da } & \text { arqi-ya } & \text { čekin-mä-s-lik } & \text { lazim. } \\ \text { difficulty } & \text { front-POSS.3sg--LOC } & \text { back-DAT } & \text { retreat-NEG-AOR-NOML } & \text { must }\end{array}$

'One must not retreat in front of the difficulty.'

$\begin{array}{lllll}\text { Ay-ni } & \text { etäk } & \text { bilän } & \text { yep-ip } & \text { bol-ma-s. } \\ \text { moon-ACC } & \text { elbow } & \text { with } & \text { cover-CONV } & \text { be-NEG-AOR }\end{array}$

'It is impossible to cover the moon with the elbow. (One couldn't hide the crystal-clear truth.)'

As Janet R. Aiken [13] pointed out, constructions lacking subject or verb or both are of a great variety of types, from the imperatives such as COME HERE and the omitted first person types WENT DOWN TOWN TODAY .... where it is difficult or impossible to construct a full sentence convincingly.

Such imperative sentence can also be impersonal in Uyghur. It is difficult to construct the agent of the sentence, since it does not agree with the agent-predicate agreement principle. E.g.:

$\begin{array}{llll}\text { Silär-nin } & \text { yardim-ijlar-ya } & \text { köp } & \text { rähmät. } \\ \text { You.pl-GEN } & \text { help-POSS.2pl-DAT } & \text { many } & \text { thank }\end{array}$

'Many thanks to your help'

$\begin{array}{ll}\text { Heyt-iniz-ya } & \text { mubaräk bol-sun. } \\ \text { Eid-POSS.2sg-DAT } & \text { happy to be-IMP.3sg }\end{array}$

'Happy ramazan festival!'

2) Incomplete sentence

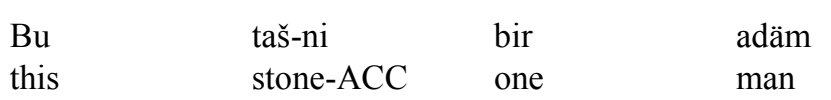

'It is impossible for one man alone to lift this stone.'

Also a conditional sentence:

$\begin{array}{llll}\text { Sän } & \text { därhal } & \text { may-sa- } y & \text { bol-idu. } \\ \text { you } & \text { immediatly } & \text { go-COND-2SG } & \text { be-NPAST }\end{array}$

These sentences are incomplete by nature, so it can be said non-sentence [13] since it is completely impracticable to supply the missing elements to make complete sentences.

This type exists in many languages, since short sentences agree with the economy principle. Main part of these sentences is indicated by nominative phrase, or it can be a short clause. e.g.:

$\begin{array}{ll}\text { Gugum } & \text { waqt-i } \\ \text { evening } & \text { time-POSS }\end{array}$

'at the nightfall'

$\begin{array}{lll}\text { Örkäšli-gän } & \text { äzim } & \text { därya. } \\ \text { surge-PARTCPL } & \text { big } & \text { sea }\end{array}$

'A surging river'

3) Existential sentence

In the agentless constructions he discussed, Litip TOHTI [12] pointed out that no human activity involves in these types of sentences, e.g.:

$\begin{array}{lll}\text { yalyuz } & \text { kötär-gili } & \text { bol-ma-ydu. } \\ \text { alone } & \text { lift-CONV } & \text { be-NEG-NPAST }\end{array}$


'It is ok that you can go immediately.'

These sentences indicate appearing or existence of something. Only place adverbs appear in the beginning of the sentence. E.g:

$\begin{array}{lll}\text { Öy-dä } & \text { adäm } & \text { bar/yoq. } \\ \text { house-LOC } & \text { human } & \text { have/haven't }\end{array}$

'there is/isn't anyone in the house.'

$\begin{array}{lll}\text { Bazar-da } & \text { adäm } & \text { köp-tur. } \\ \text { street-LOC } & \text { people } & \text { many-COP }\end{array}$

'There are lot of people on the street.'

Existence or appearing is the main information in these sentences. Therefore the place of existence must be spoken out first, otherwise it will become non-existential sentence.

4) Modal sentence

English modal verbs correspond to Uyghur modal adjectives. In these types, agent part is gerunds, predicate part is modal adjectives such as mümkin 'possible', keräk lazim 'must, should, have to', šärt 'should'.e.g.:

$\begin{array}{lllll}\text { Öy-dä } & \text { adäm } & \text { yoq } & \text { bol-iš-i } & \text { mümkin. } \\ \text { house-LOC } & \text { man } & \text { no } & \text { be-VN-POSS.3sg } & \text { possible }\end{array}$

'May be there is no one in the house.'

In this type of sentences, the modal adjectives and gerunds constitute a strict agent-predicate construction, which loosens the relationship between possessor and dependant. As a result, the genitive case drops.

a.

$$
\begin{array}{ll}
\text { Silär-nin } & \text { ätä } \\
\text { You.pl-GEN } & \text { tomorrow }
\end{array}
$$

kel-iš-inlar- // keräk

come-VB- 2pl.POSS must

b. Silär- // ätä kelišinlar keräk

'You must come tomorrow.'

5) impersonal passives

Langacker and Munro [14] argue persuasively that passive constructions are basically agentless, and that agentive phrases are derived from external sources. In this view, corresponding passive and active sentences are related semantically, but do not have a common conceptual (i.e. underlying) structure. They give evidence from a number of Uto-Aztecan languages and from Mojave, a Yuman language, to show that passives are basically impersonal constructions, derived 'from structures in which a clause with unspecified subject is embedded as subject complement to the predicate $B E$.

Explicit agents do occur with impersonal passives. Furthermore, when agents are not explicitly expressed, they are predictable from the context in a number of cases. Generally, agentless passives are derived in all cases by a transformation of indefinite agent deletion.

Passive constructions in Uyghur are produced by attaching the suffix $-n(-n /-i n)$ or $-l(-l /-i-/-u l /-\ddot{u} l)$. Passive voice indicates that the grammatical subject of the sentence is actually the logical object of the original action.

$$
\begin{array}{ll}
\text { Oyun } & \text { bašla-n-di. } \\
\text { play } & \text { start-PASS-PAST }
\end{array}
$$

'The play was begun.'

$$
\text { Xät }
$$

letter

Paša išan

Pasha Ishan yez-il-di. write-PASS-PAST

'The song performed by Pasha Ishan was applauded.'

'The letter is written.'

The passive voice is used in situations:

i. It is difficult to point out the logical subject of the action.

$\begin{array}{lllll}\mathrm{Bu} & \text { maqalä } & \text { nahayiti } & \text { yaxši } & \text { yez-il-iptu. } \\ \text { this } & \text { article } & \text { very } & \text { good } & \text { write-PASS-EVID }\end{array}$

'This article has been written extremely well.'

ii. It is unnecessary to point out the logical subject of the action:

Mämät wäkil-lik-kä sayla-n-di.

Mämät representative-NOML-DAT elect-PASS-PAST

'Mämät has been elected as a representative.'

iii. It is necessary to especially accentuate the logical object.
Düšmän-lär
yoqit-il-di.
enemy-PL
exterminate-PASS-PST

'The enemies were exterminated.'

iv. In some situations it is necessary to point out the logical subject at the same time as accentuating the logical object. In such cases, if the logical object is a person, people in general, or some organization, the noun which indicates that logical subject is combined the the proposition täripidin 'by' to form an adverbial modifier.
naxša
alqiš-qa
eriš-ti.
song
obtain-PAST 
v. If the logical subject was something else, the role of the logical subject is indicated in different ways.

$\begin{array}{lllll}\text { Därizi-nin } & \text { äynik-i } & \text { šamal-da } & \text { čeq-il-ip } & \text { kät-ti. } \\ \text { window-GEN } & \text { glass-POSS.3sg } & \text { wind-LOC } & \text { break-PASS-CONV } & \text { AUX-PAST }\end{array}$

'The window pane broke in the wind.'

\section{Some Arguments over the Nature of Impersonal Construction}

Most scholars agree on the nature of impersonal constructions. However, two authors put forward slightly different opinions.

According to the characteristics of some agentless constructions whether it can be converted into agentive ones, Niyaz TURDI [9] asserted that impersonal constructions can

\begin{tabular}{|c|c|c|c|c|c|}
\hline $\begin{array}{l}\text { Qiyinčiliq } \\
\text { difficulty }\end{array}$ & $\begin{array}{l}\text { ald-i-da } \\
\text { front-POSS.3sg -LOC }\end{array}$ & $\begin{array}{l}\text { täwrä-n-mäs-lik } \\
\text { shake-PASS-NEG-NOML }\end{array}$ & $\begin{array}{l}\text { keräk } \\
\text { must }\end{array}$ & & (impersonal) \\
\hline \multicolumn{6}{|c|}{ 'One must be unshakeable in front of difficulty.' } \\
\hline $\begin{array}{l}\text { Qiyinčiliq } \\
\text { difficulty }\end{array}$ & $\begin{array}{l}\text { ald-i-da } \\
\text { front-POSS.3sg-LOC }\end{array}$ & $\begin{array}{l}\text { täwrä-n-mäs-lik-imiz } \\
\text { shake-PASS-NEG-NOML- }\end{array}$ & SS.1pl & $\begin{array}{l}\text { keräk. } \\
\text { must }\end{array}$ & (person \\
\hline
\end{tabular}

'We must be unshakeable in front of difficulty.'

The personal marker -imiz which added to the gerund is the key factor that converts impersonal construction into personal contruction.

b) If the first part of a sentence, whose predicates is bol- 'to be', toyra käl- 'have to', is gerund, it will form an impersonal construction. If the gerund part has person marker, it forms a covert personal construction. E.g.:

$\begin{array}{lllll}\text { U-nin } & \text { öz-i } & \text { bilän } & \text { kör-üš-üš-kä } & \text { torra kel-idu. } \\ \text { He-GEN } & \text { self-POSS.3sg } & \text { with } & \text { see-REC-VN-DAT } & \text { (impersonal) } \\ \text { have to-NPAST } & \end{array}$

'It is necessary to meet his own self.'

\begin{tabular}{|c|c|c|c|c|}
\hline $\begin{array}{l}\text { U-nin } \\
\text { He-GEN }\end{array}$ & $\begin{array}{l}\text { öz-i } \\
\text { self- POSS.3sg }\end{array}$ & $\begin{array}{l}\text { bilän } \\
\text { with }\end{array}$ & $\begin{array}{l}\text { kör-üǔ-üš-imiz-gä } \\
\text { see-REC-VN-POSS.1pl-DAT }\end{array}$ & $\begin{array}{l}\text { to ra kel-idu. } \\
\text { have to-NPAST }\end{array}$ \\
\hline
\end{tabular}

'We have to meet his own self.'

c) When the head of the sentence is dative or genitive noun phrase, and after that appears the combination of gerund and toyra käl- 'have to', if the case marker drops off, the gerund also loses its possessive marker. As a result, the sentence becomes an agentive construction.e.g.

\begin{tabular}{|c|c|c|}
\hline $\begin{array}{l}\text { Mämät-kä } \\
\text { Mämät_DAT }\end{array}$ & $\begin{array}{l}\text { qayt-ip } \\
\text { go back-CONV }\end{array}$ & $\begin{array}{l}\text { ket-iš-kä } \\
\text { AUX-VN-DAT }\end{array}$ \\
\hline
\end{tabular}

'For Mämät, it is compulsory to go back.'

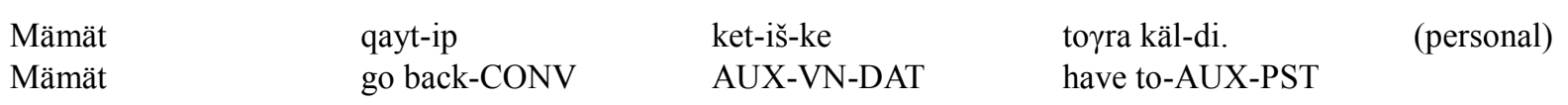

'Mämät have to go back'

2) Absolute impersonal construction

a) A sentences with third person passive predicate can be considered as absolute impersonal construction. E.g.:

$\begin{array}{llll}\text { Öginiš } & \text { waqt-i-din } & \text { toluq } & \text { paydilin-il-sun. } \\ \text { study } & \text { time-POSS.3sg-ABL } & \text { complete } & \text { use-PASS-IMP.3sg }\end{array}$

'Please make complete use of studying time!
Xizmät
usul-i- $\gamma \mathrm{a}$ work method-POSS.3sg-DAT
diqqät
attention
qil-in-sun
do-PASS- IMP.3sg

'Please pay attention to the work method.'

b) The combination of genitive pronouns and auxiliary verbs such as kör-'to see', käl-'to come', qal-'to leave, to remean', or existential adjectives such as bar 'to exist', yoq 'doesn't exist' etc. e.g.: 


\begin{tabular}{|c|c|c|c|}
\hline $\begin{array}{l}\text { U-nin } \\
\text { He-GEN }\end{array}$ & $\begin{array}{l}\text { bu } \\
\text { this }\end{array}$ & $\begin{array}{l}\text { yär-dä } \\
\text { place-LOC }\end{array}$ & 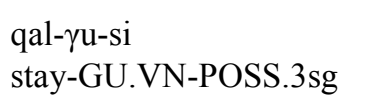 \\
\hline \multicolumn{4}{|c|}{ 'He has a wish to stay here.' } \\
\hline $\begin{array}{l}\text { Men-in } \\
\text { I-GEN }\end{array}$ & $\begin{array}{l}\text { bu } \\
\text { this }\end{array}$ & $\begin{array}{l}\text { yär-dä } \\
\text { place-LOC }\end{array}$ & $\begin{array}{l}\text { tur- } \gamma \mathrm{u}-\mathrm{m} \\
\text { stand- GU.VN- POSS.3sg }\end{array}$ \\
\hline
\end{tabular}

'I don't have any wish to stay here.'

$\begin{array}{llll}\text { Men-in } & \text { öy-üm-ni } & \text { kör-gü-m } & \text { käl-di. } \\ \text { I-GEN } & \text { house-POSS.1sg-ACC } & \text { see-GU.VN-POSS.1sg } & \text { come-PAST }\end{array}$

'I have a wish to see my home.'

3) The combination of intentive adverbial and bol- 'to be':
Yultuz-lar-ni
sana-p
tügät-kili
bol-ma-ydu.
Star-PL-ACC
count-CONV
finish-GILI.CONV
be-NEG-NPAST

'It is impossible to completely count up the stars.'

Zäynäp NIYAZ [8] argued that the sentences which had been previously defined as subjectless sentences by other grammarians were not subjectless in fact. E.g.:
Mundaq
roh-iniz-din
such
spirit-POSS.2sg-ABL
ögin-iš
keräk
learn-VN
should

'One should learn such a spirit of you.'
Hämmi-miz-nin
kel-iš-imiz
zörür.
All-POSS.1pl-GEN
come-VN-POSS.1pl
necessary

'It is necessary for all of us to come.'

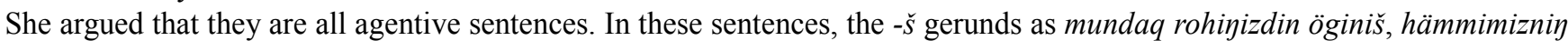
kelišimiz play the role of the subject, and keräk, lazim, zörür can play the role of predicates. She also argued that these sentences [the combination of gerunds + mümkin] as below were also mistakenly taken as subjectless:

$\begin{array}{llll}\mathrm{Bu} & \text { kitab-din } & \text { paydilin-iš } & \text { mümkin. } \\ \text { this } & \text { book-ABL } & \text { use-VN } & \text { possible }\end{array}$

'It is possible to make use of this book.'
Biz-nin
$\mathrm{u}$
yär-gä
bar-mas-liq-imiz
mümkin.
we-GEN
that
place-DAT
go-NEG-NOML-POSS.1pl possible

'Tt is likely that we go there.'

In these sentences, bu kitabdin, bizning $u$ yärgä barmasliqimiz are nominative gerunds which play the role of agents. And mümkin is a predicate whose copila -dur is omitted.

Thirdly, these sentences also belong to such mistakes:

$\begin{array}{lllll}\text { Bügün } & \text { men-in } & \text { kino- } \gamma \mathrm{a} & \text { bar- } \gamma \mathrm{u}-\mathrm{m} & \text { bar. } \\ \text { today } & \text { I-GEN } & \text { movie-DAT } & \text { go-GU.VN-POSS.1sg } & \text { has }\end{array}$

'Today I want to go to the movie.'

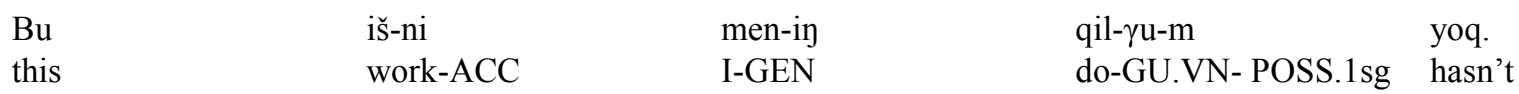

'I don't have any intention to do this work.'

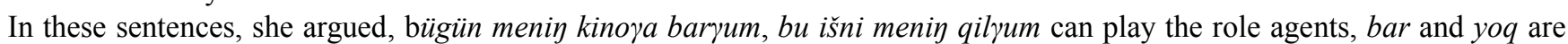
predicates.

Then, what are subjectless sentences? According to her: 'grammatikiliq igisini tapqili bolmaydiran yaki eniqlašqa mümkin

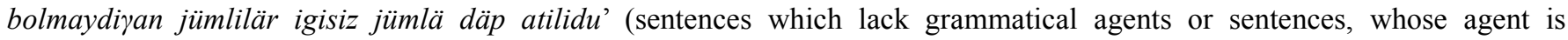
impossible to define are called agentless sentences.).e.g.:

\begin{tabular}{|c|c|c|c|c|c|}
\hline $\begin{array}{l}\mathrm{Bu} \\
\text { this }\end{array}$ & $\begin{array}{l}\text { iš-ni } \\
\text { work-ACC }\end{array}$ & $\begin{array}{l}\text { bir } \\
\text { one }\end{array}$ & $\begin{array}{l}\text { kün-dä } \\
\text { day-LOC }\end{array}$ & $\begin{array}{l}\text { tügät-kili } \\
\text { finish-GILI.CONV }\end{array}$ & $\begin{array}{l}\text { bol-ma-ydu } \\
\text { be-NEG-NPAST }\end{array}$ \\
\hline
\end{tabular}

'It is impossible to finish this work within one day.' 
U-nin
He-GEN

gep-i-gä

word-POSS.3sg-DAT

'It is difficult to understand his words.'

Since incomplete sentence (non-sentence) lack grammatical agent, she agreed that they can also be considered as subjectless sentences.

\section{Conclusion}

To sum up, Zäynäp NIYAZ [8] and Niyaz TURDI [9] put forward different opinions on the nature of impersonal constructions and narrowed the scope. They thought that such sentences as hämmimizniy kelišimiz zörür were in fact subjective sentences, and treated hämmimizniy kelišimiz as a subject. But from the point of subject predicate agreement rule in Uyghur, in which the predicate must agree with the subject in person, for instance in män käldim 'I have come', the person marker $-m$ in predicate agrees with the subject män, we have to deny their suggestions. In män käldim 'I have come', by omitting the subject män, a syntactic pleonasm will be formed. E.g.:

män käldim 'I has come'

käldim 'I has come'

In this case, the pronoun män 'I' is grammatically optional, both sentences mean 'I has come'. But in the case of Zäynäp NIYAZ [8] and Niyaz TURDI [9], the covert pronoun biz 'we' doesn't agree with the predicate zörür in person.

Another sentence type, whose agent is difficult to define, is pro-drop ambiguity sentence. E.g.:

$\begin{array}{llll}\text { Tülkä } & \text { käl-gän } & \text { täräp-kä } & \text { qari-di } \\ \text { fox } & \text { come-PARTCPL } & \text { direction-DAT } & \text { look-PAST }\end{array}$

'The fox looks at the direction from where it (the fox itself) comes.'

'The fox looks at the direction from where he (human) comes.'

'He (human) looks at the direction from where the fox comes.'

The position of covert subject is the main reason of ambiguity in this sentence. It was extensively discussed by Muzappar ABDURUSUL [14]. Here I shall limit my discussion to conventional impersonal constructions.

To sum up, impersonal constructions are one of the main sentence types of Uyghur language. It not only displays universal features, but also shows language-specific characteristics. In this preliminary study, the author has discussed the types of impersonal constructions and their formation in Uyghur. Thus, this paper will pave a way for further studies of impersonal constructions and provides important languages facts for future cross-linguistic study.

\section{References}

[1] Siewierska, Anna (2008a). Ways of impersonalizing: Pronominal vs verbal strategies. - María De Los Ángeles Gómez.
čüšän-gili
understand-GILI.CONV
bol-ma-ydu. be-NEG-NPAST

[2] Siewierska, Anna (2008b). Introduction: Impersonalization from a subject-centred vs. agent-centred perspective. In: Transactions of the Philological Society, 106/2: $115 \sim 137 \mathrm{pp}$.

[3] Andrej Malchukov, Anna Siewierska (2011). Impersonal Constructions: A Cross-Linguistic Perspective John Benjamins Publishing Company.

[4] Andrej Malchukov and Akio Ogawa (2011). Towards a typology of impersonal constructions. A semantic map approach. In: Malchukov, Andrej and Siewierska, Anna (eds.): Impersonal constructions. A cross-linguistic perspective. Amsterdam/Philadelphia: John Benjamins Publishing Company. 19 56pp.

[5] Turdi ÄXMÄT, Änsärdin MUSA, Näsrulla YOLBOLDI (1984). Hazirqi Zaman Uyghur Tili, (Aliy Mäktäblär üčün Därslik), (Modern Uyghur Grammar, A textbook for Universities), Ürümchi: Shinjiang Maarip Näshriyati.

[6] Sulayman SÄPÄR (2000). Hazirqi Zaman Uyghur Tili (Modern Uyghur Grammar), Ürümči, Šinjan Xälq Näshriyati.

[7] Xaliq NIYAZ (1982). Hazirqi Zaman Uyghur Tilidiki Addi Jümlilärning Jümlä Nusxiliri (The Types of Simple Sentences in Modern Uyghur). In: Shinjang Til-yeziq Komiteti (Language and Script Committee of Xinjiang) (ed.) Uyghur tili mäsililiri (Some Issues of the Uyghur Language). Ürümchi, Shinjang Xälq Näshriyati.

[8] Zäynäp NIYAZ (1990). Hazirqi Zaman Uyghur Tilidiki Igisiz Jümlä Toghrisida (On Subjectless Sentences in Modern Uyghur), Til Wä Tärjimä 5, 24 27pp.

[9] Niyaz TURDI (1994). Uyghur Tilidiki Igisiz Jümlilärnin Tüzüliši Häqqidä (On The Formation of Subjectless Sentences In Uyghur), Til Wä Tärjimä 6, 37 38pp.

[10] Cheng, Shiliang et al. (eds.) (1996). Xiandai weiwuer yu yufa. Hazirqi Zaman Uyghur tili grammatikisi. [Modern Uyghur grammar] (In Chinese and Uyghur). Ürümči, Šinjang Xälq Näšriyati.

[11] Hämit TÖMÜR (2003). Translated by Ann Lee, Modern Uyghur Grammar (Morphology), Yildiz Dil Ve Edebiyat 3, Istanbul.

[12] Litip TOHTI (2004). From Phrase Structure to Minimalist Program: The Syntactic Structure of Altaic Languages. Beijing: MUC Publishing House.

[13] Janet R. Aiken The Subjectless Imperative (1936). Modern Language Notes, Vol. 51, No. 4, pp. 273-274. The Johns Hopkins University Press.

[14] Ronald W. Langacker and Pamela Munro (1975). Passives and Their Meaning, Language, Vol. 51, No. 4 (Dec., 1975), pp. 789-830, Published by: Linguistic Society of America.

[15] Muzappar ABDURUSUL (2009). Adjectivalized phrase or relative clause in Uyghur. Manchu Studies 2 (53-57). Heilongjiang University). 


\section{Biography}

Muzappar Abdurusul, Chinese Uyghur, born on 20th Oct 1974, Uchturpan, Xinjiang Uyghur Autonomous Region, China, presently working at The Editorial Office of 'Minority Languages of China', Institute of Ethnology and Anthropology, Chinese Academy of Social Sciences, Beijing, China. Editor and Associate Researcher. Mainly studies Altaic languages and Generative Grammar, authors two books: Substantive Phrases in Uyghur: A Study in the Frame of Minimalist Program. (The Ethnic Publishing House, Beijing, 2014) and Uchturpan Subdialect of Uyghur (China Social Sciences Press, Beijing, 2017), and two dozen articles. 